\title{
LITERASI MEDIA BARU MAHASISWA FAKULTAS AGAMA ISLAM UNIVERSITAS ISLAM RIAU
}

\author{
Uthi Kurnia*), Nining Sudiar **), Vita Amelia***) \\ Fakultas Ilmu Budaya Universitas Lancang Kuning, Pekanbaru Indonesia \\ Email: uthikurnia@gmail.com*), sudiar.nining@gmail.com **), vita.amelia@unilak.ac.id***)
}

Naskah diterima: 7 November; direvisi: 14 November; disetujui: 28 November

\begin{abstract}
Abstrak
Penelitian ini berjudul Literasi Media Baru Mahasiswa Falultas Agama Islam Universitas Islam Riau. Tujuan penelitian ini adalah untuk mengetahui tingkat literasi media baru Mahasiswa Fakultas Agama Islam Universitas Islam Riau. Jenis penelitian ini adalah deskriptif kuantitatif, dengan objek penelitian literasi media baru Mahasiswa Fakultas Agama Islam Universitas Islam Riau. Subjek penelitian ini adalah Mahasiswa Fakultas Agama Islam Universitas Islam Riau dengan responden berjumlah 89 orang. Hasil penelitian menunjukkan bahwa literasi media baru Mahasiswa Fakutas Agama Islam Universitas Islam Riau berada pada kategori sangat baik dengan persentase 79,81\%. Hasil analisis data responden menunjukkan bahwa secara keseluruhan literasi media baru Mahasiswa Fakultas Agama Islam Universitas Islam Riau untuk masing-masing indikator berada pada kategori sangat baik hanya saja dengan persentase yang berbeda-beda. Jika dijabarkan per indikator maka didapatkan bahwa kemampuan tertinggi berada pada indikator Performance yaitu 84,41\%. Kemudian di posisi ke dua yaitu indikator Play dengan persentase sebesar $82,96 \%$. Di posisi ke tiga adalah indikator Networking dengan persentase sebesar $82,68 \%$. Posisi ke empat adalah Visualisation dengan persentase sebesar 82,23\%. Posisi ke lima dan ke enam ada pada indikator Distributed Cognition dan Transmedia Navigation dengan persentase masing-masing sebesar $81,60 \%$ dan $80,34 \%$. Posisi ke tujuh adalah Negotiation dengan persentase sebesar 80,13\%. Sisanya juga termasuk dalam kategori sangat baik namun dengan persentase di bawah $80 \%$, yaitu di posisi delapan dan sembilan yang di tempati oleh Simulation dan Appropriation dengan persentase masing-masing sebesar $79,14 \%$ dan $78,93 \%$. Indikator Judgment dengan persentase sebesar 78,00\%, Collective Intelligence dengan persentase sebesar 77,67\% dan peringkat terbawah ada pada indikator Multitasking dengan persentase sebesar 77,53\%.
\end{abstract}

Kata kunci: Literasi Media Baru, Mahasiwa Fakultas Agama Islam, Universitas Islam Riau

\begin{abstract}
The title of this research is new media literacy of undergraduate student in Faculty of Islamic Studies, Islamic University of Riau, Pekanbaru. This study aims to identify the level of new media literacy amongst students. This study conducts descriptive qualitative method by distributing questioner to 89 students and describing the result thoroughly. There are 12 indicators examined: performance, play, networking, visualization, distributed cognition, transmedia navigation, negotiation, simulation, appropriation, judgment, collective intelligence, and multi tasking. The result shows that students' new media literacy is good. Around $79,81 \%$ students are able to perform new media literacy well. From all indicators, "performance" placed the highest score around $84,41 \%$ followed by play (82,96\%), networking (82,68\%), visualisation (82,23\%), distributed cognition $(81,60 \%)$, transmedia navigation $(80,34 \%)$, negotiation $(80,13 \%)$, simulation $(79,14 \%)$, appropriation $(78,93 \%)$, judgment (78,00\%), collective intelligence $(77,67 \%)$ and multitasking $(77,53 \%)$.
\end{abstract}

Keyword: New Media Literacy, Undergraduate Student in Faculty of Islamic Studies, Islamic University of Riau 


\section{Latar Belakang}

Literasi, secara sederhana diartikan kemapuan membaca dan menulis atau melek aksara/ huruf. Seiring kemajuan ilmu pengetahuan, makna sederhana tersebut juga mengalami cakupan yang meluas, yang tidak hanya terbatas pada kemampuan membaca dan menulis semata, tetapi juga mencakup kemampuan menggunakan informasi tertulis atau tercetak untuk mengembangkan pengetahuan sehingga mendatangkan manfaat bagi masyarakat. Bisa juga dikatakan melek terhadap teknologi, melek terhadap politik, berpikir kritis dan peka terhadap lingkungan sekitar (Ardianto, dkk., 2009: 215).

Menurut Brevik, literasi informasi (melek keberaksaraan informasi), yaitu mengetahui kapan informasi dibutuhkan, kemudian melakukan identifikasi terhadap kebutuhan informasi dalam memberikan solusi terhadap permasalahan yang ada, menemukan informasi yang dibutuhkan, mengolah informasi tersebut sehingga bisa digunakan secara efektif untuk peyelidikan masalah atau penelitian yang sedang dilakukan (Yulianti, 2013: 2). Seperti itulah rangkaian kegiatan literasi informasi dalam mengolah sebuah informasi sehingga menjadi sesuatu yang bermanfaat untuk memenuhi kebutuhan informasi para pencari informasi maupun para penerima informasi.

Informasi dan media ibarat dua sisi mata uang, yaitu sesuatu yang tidak dapat dipisahkan. Dikatakan demikian karena media merupakan sarana penyampai informasi. Tidak akan ada informasi jika tidak ada media atau perantara yang menyampaikannya. Media mengalami perkembangan dari masa ke masa. Dahulu manusia menyebarkan informasi menggunakan media panca indra, kemudian ditemukan kertas dan tinta sampai terlahirlah media cetak seperti buku, koran, majalah, dan lain sebagainya. Kemudian berkembang lagi media elektronik seperti radio dan televisi. Perkembangan terakhir dari media komunikasi yaitu munculnya media internet sebagai media baru yang mampu menyebarkan informasi secara luas tanpa batas. Kehadiran internet menyempurnakan segala media yang ada sebelumnya yaitu menggabungkan media cetak yang hanya bisa dilihat, radio yang hanya bisa didengar, serta televisi yang bisa dilihat dan didengar. Kini seseorang tidak harus kesulitan menggunakan media lama tersebut karena cukup dengan internet saja, semua informasi dalam media cetak sudah dikemas menjadi satu dan dengan mudah bisa didapatkan. Itulah mengapa media internet saat ini begitu sangat diminati dari pada media lainnya.

Literasi media atau melek media, suatu istilah yang digunakan sebagai jawaban atas maraknya pandangan masyarakat tentang pengaruh dan dampak yang timbul akibat isi (content) berbagai pemberitaan di media yang belum tentu kebenarannya. Sehingga perlu diberikan suatu kemampuan, pengetahuan, kesadaran dan keterampilan secara khusus kepada khalayak sebagai pengguna media baru terutama internet.

Mahasiswa merupakan komunitas yang termasuk aktif menggunakan internet. Hal ini dikarenakan mahasiwa merupakan kaum intelektual terdidik. Mahasiswa memiliki tugas dan kewajiban utama yaitu melaksanakan pendidikan di mana dalam perkuliahan dituntut mempunyai informasi dan wawasan yang cukup luas agar selama di kelas maupun di luar kelas mampu melakukan diskusi dengan baik. Mahasiswa dituntut untuk belajar namun juga memiliki kewajiban untuk meneruskan kepada masyarakat luas tentang ilmu pengetahuan yang dimilikinya. Mahasiswa dituntut sensitif terhadap beragam gejala dan fenomena yang ada di lingkungannya. Merumuskan gejala-gejala tersebut ke dalam sebuah penelitian untuk diuji dan dibuktikan. Tugas mahasiswa selanjutnya adalah mengabdi kepada masyarakat. Pengabdian ini merupakan bentuk kontribusi mahasiswa kepada masyarakat sebagai wujud dari ilmu pengetahuan yang didapatkannya. Hal itulah yang menjadikan mahasiswa sangat bergantung dengan informasi, tak terkecuali informasi yang disajikan di internet. Fakultas Agama Islam adalah salah satu fakultas yang ada di bawah naungan Univerisitas Islam Riau. Data terakhir menunjukkan bahwa mahasiswa aktif di Fakultas Agama Islam berjumlah 835 orang. Berdasarkan pengamatan selama melakukan Praktik Kerja Lapangan di Fakultas Agama Islam Universitas Islam Riau, terlihat bahwa keseharian mahasiswa Fakultas Agama Islam tidak terlepas dari berbagai media informasi seperti buku, berbagai media sosial seperti facebook, WhatsApp, Line, dan sejenisnya, dan juga sebagian besar di antara mereka memanfaatkan search engine sebagai media pencari informasi untuk tugas kuliah dan penelitian. Ketika diajukan pertanyaan yang sama kepada beberapa mahasiswa di sana, yaitu pada Hari Selasa, 23 Januari 2018 tentang media apa yang lebih dominan mereka gunakan untuk kegiatan pembelajaran semuanya menjawab internet dan hanya beberapa yang menambahkan dengan buku dan jurnal ilmiah. 
Wawancara sederhana dengan mahasiswa di Fakultas Agama Islam Universitas Islam Riau dilakukan kembali pada Hari Rabu tanggal 23 Januari 2018, didapati belum pernah ada pembelajaran ataupun pelatihan literasi media baru terutama internet dengan program yang lebih terfokus. Padahal sebenarnya pelatihan keterampilan literasi internet penting untuk dilakukan dengan pertimbangan masyarakat Fakultas Agama lslam selalu memanfaatkan media internet.

Hal ini menjadi menarik untuk dilakukan penelitian demi mengetahui sejauh mana mahasiswa Fakultas Agama Islam Universitas Islam Riau Literate terhadap media baru meskipun belum pernah mendapat pembekalan literasi media baru. Rumusan masalah dalam penelitian ini adalah bagaimanakah Literasi Media Baru Mahasiswa Fakultas Agama Islam Universitas Islam Riau? Sedangkan tujuan penelitian ini adalah untuk mengetahui Literasi Media Baru Mahasiswa Fakultas Agama Islam Universitas Islam Riau.

\section{Tinjauan Pustaka \\ 2.1 Literasi}

Literasi, secara sederhana diartikan kemapuan membaca dan menulis atau melek aksara/ huruf. Seiring kemajuan ilmu pengetahuan, makna sederhana tersebut juga mengalami cakupan yang meluas, yang tidak hanya terbatas pada kemampuan membaca dan menulis semata. Tetapi juga mencakup kemampuan menggunakan informasi tertulis atau tercetak untuk mengembangkan pengetahuan sehingga mendatangkan manfaat bagi masyarakat. Bisa juga dikatakan melek terhadap teknologi, melek terhadap politik, berpikir kritis dan peka terhadap lingkungan sekitar (Ardianto,dkk., 2009: 215).

\subsection{Media}

Media berawal dari komunikasi massa yang melahirkan media massa. Secara konvensional media massa diartikan sebagai medium pembawa pesan yang memiliki jangakauan luas, baik dilihat dari aspek pemanfaatannya, sebarannya, maupun orang yang terlibat di dalamnya. Secara tradisional media massa sering dibatasi pada surat kabar, radio, televisi, film, buku, jurnal dan majalah. Kemajuan teknologi informasi menjadikan semua media massa konvensional tersebut saat ini sudah beralih media menjadi sumber digital yang bisa ditemukan dengan mudah di internet (Yusup, 2016: 128).
Flew dalam Tamburaka (2013: 72) mengartikan media digital sebagai bentuk dari konten media yang menggabungkan dan mengintegrasikan data, teks, suara, dan berbagai gambar yang tersimpan dalam format digital kemudian didistribusiakan melalui suatu jaringan seperti kabel serat optik, satelit, dan sistem transmisi gelombang rendah. Peralihan dari media tradisional ke media teknologi digital ini membawa perubahan besar dalam cara manusia berkomunikasi. Sebelumnya, khalayak dikendalikan oleh informasi dari lembaga penyedia media massa, setelah muncul digitalisasi khalayak tidak lagi semata-mata dikendalikan oleh informasi yang disediakan media massa tetapi media massa dan khalayak bisa memiliki kedudukan yang sama dalam menciptakan informasi.

Online media (media online) disebut juga cybermedia (media siber), internet media (media internet), dan new media (media baru) diartikan sebagai media yang tersaji secara online di situs web (website) internet. Secara teknis atau fisik, media online adalah media berbasis telekomunikasi dan multimedia (komputer dan internet). Termasuk kategori media online adalah portal, website (situs web, termasuk blog dan media sosial seperti facebook dan twitter), radio online, TV online, dan e-mail (Romli, 2012:30).

Internet, jaringan komputer terkoneksi secara global yang berkomunikasi secara bebas serta berbagi dan bertukar informasi (Baran, 2012: 389). Internet adalah perkakas sempurna yang menyiagakan dan mengumpulkan sejumlah besar orang secara elektronis. Informasi mengenai suatu peristiwa tertentu dapat ditransmisikan secara langsung, sehingga membuatnya menjadi suatu piranti meriah yang sangat efektif (Ardianto, dkk., 2009: 153).

\subsection{Literasi Media}

Literasi menurut Bambang Kaswanti Purwo (Guru Besar Linguistik Pascasrjana Unika Indonesia Atmajaya) dalam kata pengantar buku Literasi Informasi: 7 Langkah Knowledge Management, literasi tidak lagi diartikan terbatas pada "baca dan tulis" melainkan berurusan dengan belajar sepanjang hayat, mengubah cara belajar sampai kepada kembali belajar (Lien, dkk., 2014: xiii). Tamburaka menambahakan, literasi media berasal dari bahasa Inggris yaitu Media Literacy. Media berarti tempat pertukaran pesan dan Literacy berati melek. Kemudian dikenal menjadi literasi media yang bermakna kemampuan khalayak yang melek terhadap media dan pesan media 
massa dalam konteks komunikasi massa. Sementara menurut Baran dan Dennis literasi media itu merupakan suatu gerakan melek media yang dirancang dengan tujuan untuk individu memberikan kontrol atas penggunaan konten media baik dalam hal menerima ataupun mengirim pesan (Tamburaka, 2013: 8 dan 17). Literasi media merupakan suatu kompetensi yang penting untuk memberikan kesadaran tentang konten dan dampak media serta menjadi kontrol individu dalam menggunakan media (Siyamitri, 2015: 162).

Menurut Kamus Kepustakawanan Indonesia, litersi media yaitu kemampuan dan keterampilan memanfaatkan berbagai media, baik elektronik maupun non elektronik dalam rangka memperoleh informasi dan pemahaman yang meluas (Lasa, 2009: 190). Potter mengatakan bahwa literacy media adalah sebuah perspektif yang digunakan secara aktif ketika individu mengakses media. Perspektif dibangun dari struktur pengetahuan.Untuk membangun struktur pengetahuan dibutuhkan alat dan raw material (bahan dasar). Alat yang dimaksud adalah keterampilan. Sementara bahan dasarnya berupa informasi dari media dan dari dunia nyata (Ardianto, dkk., 2009: 215).

Lima elemen literasi media menurut Art Silverblatt dalam Tamburaka (2013: 12), yaitu:

a. Kesadaran akan dampak media pada individu dan masyarakat.

b. Pemahaman atas proses komunikasi masa.

c. Pengembangan strategi untuk menganalisis dan mendiskusikan pesan media.

d. Kesadaran atas konten media sebagai sebuah teks yang memberikan pemahaman kepada budaya kita dan diri kita sendiri.

e. Pemahaman kesenangan, pemahaman dan apresiasi yang ditingkatkan terhadap konten media.

Potter memperluas cakupan kegiatan literasi media, yaitu:

a. Melek media adalah sebuah rangkaian, bukan pengelompokan.

b. Melek media perlu dikembangkan.

c. Melek media merupakan multidimensional yang terdiri dari, kognitif, emosi dan estetika

d. Moral, kemampuan untuk menangkap makna yang mendasari pesan.

e. Tujuan dari melek media adalah untuk memberikan lebih banyak kontrol atas penafsiran.

\subsection{Tujuan Literasi Media}

Tujuan mendasar literasi media adalah mengajar pengguna media untuk menganalisis pesan yang disampaikan oleh media massa, mempertimbangkan tujuan komersil dan politik dibalik suatu citra atau pesan media, dan meneliti siapa yang bertanggung jawab atas pesan atau ide yang diimplikasikan oleh pesan atau citra itu (Tamburaka, 2017: 16-17). Konferensi Tingkat Tinggi mengenai Penanggulangan Dampak Negatif Media Massa di Berlin, Jerman pada 7-8 Maret 2002 menghasilkan buku berjudul " $21^{\text {st }}$ Century in a Convergent Media Word."

\subsection{Konsep Literasi Media}

Delapan konsep literasi media menurut Ardianto, dkk. (2009: 221) adalah:

a. Media merupakan sebuah bangunan. Literasi media berperan memisahkan bagian-bagian bangunan untuk menunjukkan bagaimana sebuah bangunan bisa dihasilkan.

b. Media membangun realitasi. Media bertanggung jawab terhadap cara pandang seseorang terhadap pemahaman dan pengalamannya tentang dunia.

c. Khalayak menyesuaikan pemahaman masing-masing orang terhadap apa yang ditampilkan media.

d. Media memiliki implikasi komersial. Literasi media bertujuan mengembangkan kesadaran tentang bagaimana media dipengaruhi oleh aspek komersial, dan bagaimana aspek komersial tersebut mempengaruhi isi, teknik penyajian dan distribusi.

e. Media mengandung ideologi dan pesnpesan yang memiliki nilai tertentu.

f. Media memiliki implikasi terhadap aspek sosial dan politik yang berpengaruh terhadap perubahan sosial khalayak.

g. Bentuk dan isi media saling berkaitan.

h. Masing-masing media memiliki bentuk estetika yang unik.

Kehadiran media baru menuntut diselenggarakannya program-program literasi media yang terfokus pada media baru dan media sosial, antara lain dengan berpatokan pada 12 dasar atau landasan yang dirancang oleh Jenkins, dkk. seperti tampak pada tabel berikut:

Tabel 1. Landasan Teori Literasi Media Baru

\begin{tabular}{|c|c|l|}
\hline No & $\begin{array}{c}\text { Landasan } \\
\text { Teori }\end{array}$ & \multicolumn{2}{|c|}{ Keterangan } \\
\hline 1 & Play & \multicolumn{2}{|l|}{ Kemampuan menggunakan } \\
yaitu mengakses dan \\
mengeksplorasi media baru.
\end{tabular}




\begin{tabular}{|c|c|c|}
\hline 2 & Performance & $\begin{array}{lr}\text { Kemampuan } & \text { bermain peran } \\
\text { untuk } & \text { meningkatkan } \\
\text { improvisasi } & \text { dan } \\
\text { mempelajari } & \text { pengalaman } \\
\text { sebelumnya. } & \end{array}$ \\
\hline 3 & Simulation & $\begin{array}{l}\text { Kemampuan } \\
\text { menginterpretasikan dan } \\
\text { menyelewengkan informasi } \\
\text { pada media baru. Ini } \\
\text { didapat melalui trial and } \\
\text { error yang dilakukan } \\
\text { melalui eksperimen, } \\
\text { berhipotesis dan melakukan } \\
\text { pengujian. }\end{array}$ \\
\hline 4 & $\begin{array}{c}\text { Appropriatio } \\
n\end{array}$ & $\begin{array}{l}\text { Proses mengambil sebagian } \\
\text { budaya dan menyatukan } \\
\text { dengan berbagai konten. }\end{array}$ \\
\hline 5 & Multitasking & $\begin{array}{l}\text { Kemampuan memindai } \\
\text { lingkungan dan fokus } \\
\text { terhadap elemien-elemen } \\
\text { pesan. Dua hal yang harus } \\
\text { diperhatikan dalam hal ini } \\
\text { yaitu perhatian (atensi) } \\
\text { yang berarti kemapuan } \\
\text { mengkritisi informasi asing } \\
\text { dan fokus pada rincian } \\
\text { informasi sehingga bisa } \\
\text { mengontrol informasi yang } \\
\text { masuk ke dalam memori } \\
\text { otak kemudian memindai } \\
\text { dan mengkategorikan } \\
\text { informasi sehingga dapat } \\
\text { mengontrol informasi. }\end{array}$ \\
\hline 6 & $\begin{array}{l}\text { Distributed } \\
\text { Cognition }\end{array}$ & $\begin{array}{lr}\text { Kemampuan } & \text { berinteraksi } \\
\text { dengan media } & \text { baru untuk } \\
\text { memperluas } & \text { kapasitas } \\
\text { mental. Berinteraksi dengan } & \text { artinya } \\
\text { media baru } & \text { artas } \\
\text { menyadari peran masing- } & \text { masing elemen yang ada. } \\
\text { masing } \\
\text { Memperluas } \\
\text { mental berarti kapasitas } \\
\text { dalam masitas } \\
\text { masalah saat berinteraksi di } \\
\text { dunia maya dan dapat } \\
\text { diterapkan dalam } \\
\text { pemecahan masalah di } \\
\text { dunia nyata. Kemampuan } \\
\text { ini dapat membawa } \\
\text { kecerdasan } \\
\text { terdistribusi antara otak, } \\
\text { tubuh dan dunia nyata. }\end{array}$ \\
\hline 7 & $\begin{array}{l}\text { Collective } \\
\text { Intelligence }\end{array}$ & $\begin{array}{l}\text { Kemampuan menyatukan } \\
\text { dan membandingkan } \\
\text { pendapat pengguna dengan } \\
\text { pendapat orang lain untuk } \\
\text { menuju tujuan bersama. } \\
\text { Pengguna yang memiliki } \\
\text { ketertarikan bersama } \\
\text { cenderung akan membuat } \\
\text { suatu komunitas tersendiri, } \\
\text { mereka akan saling berbagi } \\
\text { pengetahuan. Pengetahuan } \\
\text { inilah yang berubah dari } \\
\text { konsumsi pribadi menjadi }\end{array}$ \\
\hline
\end{tabular}

\begin{tabular}{|c|c|c|}
\hline & & konsumsi komunitas. \\
\hline 8 & Judgment & $\begin{array}{l}\text { Kemampuan mengevaluasi } \\
\text { keandalan dan kredibiltas } \\
\text { sumber-sumber informasi } \\
\text { yang berbeda, sekalipun } \\
\text { diperoleh dari komunitas } \\
\text { yang sama belum tentu } \\
\text { informasi itu kredibel. } \\
\text { Artinya, ada kemungkinan } \\
\text { informasi yang diterima itu } \\
\text { cacat atau bahkan salah. } \\
\text { Pengguna harus berfikir } \\
\text { untuk membaca semua } \\
\text { sumber informasi dan } \\
\text { berpikir kritis. }\end{array}$ \\
\hline 9 & $\begin{array}{l}\text { Transmedia } \\
\text { Navigation }\end{array}$ & $\begin{array}{l}\text { Kemampuan mengikuti alur } \\
\text { informasi, memburu dan } \\
\text { mengumpulkan informasi. }\end{array}$ \\
\hline 10 & Networking & $\begin{array}{lr}\text { Kemampuan mencari, } \\
\text { mensintesa, dan } \\
\text { menyebarkan informasi. }\end{array}$ \\
\hline 11 & Negotiation & $\begin{array}{l}\text { Kemampuan memahami dan } \\
\text { menghargai berbagai } \\
\text { perspektif serta berpegang } \\
\text { dan mengikuti norma di } \\
\text { setiap komunitas. }\end{array}$ \\
\hline 12 & Visualisation & $\begin{array}{l}\text { Kemampuan membuat dan } \\
\text { memahami informasi untuk } \\
\text { mengekspresikan ide, } \\
\text { menemukan pola dan } \\
\text { menginterpretasikan trend. }\end{array}$ \\
\hline
\end{tabular}

Sumber: Jenkins (2006) dalam Absyari (2017: 1418)

\section{Metode Penelitian}

Sebagai objek dari penelitian ini adalah literasi media baru oleh mahasiswa Fakultas Agama Islam Univeristas Islam Riau. Penelitian ini menggunakan teori literasi media baru sebagai indikator penelitian. Penelitian ini berjenis deskriptif kuantitatif. Metode pengumpulan data yang digunakan adalah, Observasi, Angket, dan Studi pustaka. Populasi dalam penelitian ini adalah keseluruhan mahasiswa Fakultas Agama Islam Universitas Islam Riau dengan jumlah mahasiswa di tahun ajaran 2017/2018 adalah 835 orang, dengan jumlah sampel 89.

Metode analisis data yang dilakukan dalam penelitian ini ialah dengan metode statistik deskriptif yaitu penyajian data dengan tabel dan persentase. Data angket yang dikumpulkan dibuat rekapitulasi selanjutnya data ditransformasikan dari data kualitatif menjadi data kuantitatif dengan memberikan skor pada angket. Dalam menentukan skor atau bobot nilai jawaban setiap pernyataan digunakan skala Likert. Setelah dibuat rekapitulasi, kemudian dilakukan perhitungan untuk menentukan frekuensi. Analisis data dilakukan dengan menggunakan rumus persentase 
Kriteria jawaban dan skor pada tabel di atas digunakan untuk mentransformasikan data kualitatif berdasarkan jawaban dari para responden pada angket menjadi data kuantitatif dari setiap indikator yang digunakan. Berdasarkan data skor yang telah ditetapkan, akan dihitung jawaban dari responden yang selanjutnya akan dibandingkan dengan skor ideal (kriterium) untuk seluruh item dan disajikan secara kontinum.

\section{Pembahasan dan Hasil}

\subsection{Literasi Media Baru Mahasiswa Berdasarkan Indikator}

\section{a. Play}

Play yaitu mengakses dan mengeksplorasi media baru. Mengakses berarti kemampuan melakukan pencarian di media internet sementara eksplorasi berkaitan dengan melakukan penelusuran berbagai situs yang ada di internet. Indikator Play masing-masing terlihat sebagaimana tabel berikut:

Tabel 1. Distribusi Frekuensi Indikator Play

\begin{tabular}{|c|c|c|}
\hline Keterangan & F & $\mathbf{\%}$ \\
\hline Selalu & 99 & 37,08 \\
\hline Sering & 154 & 57,68 \\
\hline Kadang-kadang & 14 & 5,24 \\
\hline Tidak Pernah & 0 & 0,00 \\
\hline Jumlah & 267 & 100 \\
\hline
\end{tabular}

Sumber: Data Olahan September 2018

Analisis data menunjukkan bahwa tanggapan responden terhadap kemampuan mengesplorasi berbagai situs pada internet lebih sering dilakukan dari pada mempertimbangkan menggunakan internet dengan baik atau memanfaatkan segala fasilitas yang tersedia di internet secara positif.

\section{b. Performance}

Performance berhubungan dengan kemampuan bermain peran untuk meningkatkan improvisasi dan mempelajari pengalaman sebelumnya. Dalam hal ini yang ingin diketahui yaitu kemampuan spontanitas dalam membaca, mempelajari, menambah wawasan dan mengambil dampak positif dari memanfaatkan media baru. Indikator Performance didapati sebagaimana tabel berikut:

Tabel 2. Distribusi Frekuensi Indikator Performance

\begin{tabular}{|c|c|c|}
\hline Keterangan & F & \% \\
\hline Selalu & 145 & 40,73 \\
\hline
\end{tabular}

\begin{tabular}{|c|c|c|}
\hline Sering & 200 & 56,18 \\
\hline Kadang-kadang & 11 & 3,09 \\
\hline Tidak Pernah & 0 & 0,00 \\
\hline Jumlah & 356 & 100 \\
\hline
\end{tabular}

Analisis data menunjukkan bahwa responden lebih sering beranggapan kalau memanfatkan inernet memberikan dampak positif terhadap kehidupan di dunia nyata.

\section{c. Simulation}

Simulation berhubungan dengan kemampuan menginterpretasikan dan menyelewengkan informasi pada media internet. Secara sederhana dapat diartikan kemampuan mempertanyakan kebenaran informasi, membandingkan dengan konteks dunia nyata, membandingkan dengan sumber lain serta memberikan penilain akhir terhadap informasi yang diterima dari internet. Indikator Simulation tampak sebagaimana tabel berikut:

\section{Tabel 3. Distribusi Frekuensi Indikator} Simulation

\begin{tabular}{|c|c|c|}
\hline Keterangan & F & \% \\
\hline Selalu & 83 & 23,31 \\
\hline Sering & 249 & 69,94 \\
\hline Kadang-kadang & 24 & 6,74 \\
\hline Tidak Pernah & 0 & 0,00 \\
\hline Jumlah & $\mathbf{3 5 6}$ & $\mathbf{1 0 0}$ \\
\hline
\end{tabular}

Sumber: Data Olahan September 2018

Analisis data menunjukkan bahwa kebanyakan responden lebih sering langsung memberikan penilaian akhir terhadap informasi yang didapatnya di internet dari pada terlebih dahulu harus mempertanyakan kebenaran, membandingkannya dengan kenyataan yang ada ataupun membandingkan dengan situs lainnya.

\section{d. Appropriation}

Secara sederhana berati kemampuan mengutip informasi dari media baru dengan mencantumkan sumber informasi serta memahami konsekuensi dari membagikan informasi di dunia maya. Indikator Appropriation menghasilkan tabel distribusi frekuensi sebagaimana tabel berikut:

Tabel 4. Distribusi Frekuensi Indikator Appropriation

\begin{tabular}{|c|c|c|}
\hline Keterangan & F & $\mathbf{\%}$ \\
\hline Selalu & 45 & 25,28 \\
\hline Sering & 116 & 65,17 \\
\hline
\end{tabular}




\begin{tabular}{|c|c|c|} 
Kadang-kadang & 17 & 9,55 \\
\hline Tidak Pernah & 0 & 0,00 \\
\hline Jumlah & 178 & 100 \\
\hline
\end{tabular}

Sumber: Data Olahan September 2018

Analisis data yang dilakukan menunjukkan bahwa responden paham terhadap konsekuensi dari membagikan informasi yang ada di internet tetapi masih ada diantaranya yang hanya kadang-kadang mencantumkan sumber ketika membagikan informasi di internet.

\section{e. Multitasking}

Secara sederhana dapat diartikan mampu melakukan pemindaian terhadap informasi yang tidak dibutuhkan serta fokus terhadap informasi yang berguna dan diperlukan saja.

Tabel 5. Distribusi Frekuensi Multitasking

\begin{tabular}{|c|c|c|}
\hline Keterangan & $\mathbf{F}$ & $\%$ \\
\hline Selalu & 17 & 19,10 \\
\hline Sering & 65 & 73,03 \\
\hline Kadang-kadang & 6 & 6,74 \\
\hline Tidak Pernah & 1 & 1,12 \\
\hline Jumlah & 89 & 100,00 \\
\hline
\end{tabular}

Analisis data menunjukkan bahwa sebagian besar responden sudah cerdas dalam melakukan sortir terhadap informasi yang dibutuhkannya meskipun ada satu orang diantaranya tidak pernah melakukan pemindaian ketika memanfaatkan internet.

\section{f. Distributed Cognition}

Secara sederhana dapat diartikan memahami segala elemen yang sering ditemui di internet. Hasil tabulasi data untuk indikator Distributed Cognition tampak sebagaimana tabel berikut:

Tabel 6. Distribusi Frekuensi Indikator Distributed Cognition

\begin{tabular}{|c|c|c|}
\hline Keterangan & F & $\mathbf{\%}$ \\
\hline Selalu & 58 & 32,58 \\
\hline Sering & 110 & 61,80 \\
\hline Kadang-kadang & 9 & 5,06 \\
\hline Tidak Pernah & 1 & 0,56 \\
\hline Jumlah & 178 & 100 \\
\hline
\end{tabular}

Sumber: Data Olahan September 2018

Analisis data menunjukkan bahwa pemahaman respendon antara elemen share (bagikan) dengan elemen like (suka) memiliki keseimbangan yang sama hanya saja satu orang diantaranya menyatakan tidak pernah membagikan memanfaatkan elemen share.

\section{g. Collective Intelligence}

Secara sederhana dapat diartikan melewati proses menerima informasi, membandingkan dengan informasi lain, menambahkan dengan pengetahuan sendiri serta menyimpulkan informasi tersebut. Hasil tabulasi untuk indikator Collective Intelligence tampak sebagaimana tabel berikut:

Tabel 7. Distribusi Frekuensi Indikator Collective Intelligence

\begin{tabular}{|c|c|c|}
\hline \\
\hline Keterangan & $\mathbf{F}$ & $\%$ \\
\hline Selalu & 82 & 23,03 \\
\hline Sering & 234 & 65,73 \\
\hline Kadang-kadang & 36 & 10,11 \\
\hline Tidak Pernah & 4 & 1,12 \\
\hline Jumlah & 356 & 100 \\
\hline
\end{tabular}

Analisis data menunjukkan bahwa ada keseimbangan jawaban responden antara kemampuan membandingkan dan menyatukan pengetahuan dengan kemampuan menyertakan pengetahuan serta menyimpulkan hasil dari informasi yang di peroleh di internet. Hal ini berarti tanggapan responden untuk melakukan tahapan atau proses mengolah informasi dilakukan dengan seimbang.

\section{h. Judgment}

Secara sederhana diartikan sebagai kemampuan kritis terhadap informasi beserta sumber informasi tersebut. Hasil tabulasi data mahasiswa untuk indikator Judgment tampak sebagaimana tabel berikut:

Tabel 8. Distribusi Frekuensi Indikator Judgment

\begin{tabular}{|c|c|c|}
\hline Keterangan & $\mathbf{F}$ & $\%$ \\
\hline Selalu & 62 & 23,22 \\
\hline Sering & 175 & 65,54 \\
\hline $\begin{array}{l}\text { Kadang- } \\
\text { kadang }\end{array}$ & 30 & 11,24 \\
\hline Tidak Pernah & 0 & 0,00 \\
\hline Jumlah & 267 & 100 \\
\hline
\end{tabular}

Hasil analisis data menunjukkan bahwa dari tiga pernyataan sebagai tolak ukur yang ajukan, responden ternyata lebih sering menganalisa langsung keterpercayaan sumber informasi dari pada harus mencari dan 
membandingkan informasi tersebut dengan situs lainnya. Hal ini berarti jika mereka sudah menyakini akan satu situs di internet, mereka akan cenderung lebih sering memanfaatkan situs tersebut sebagai sumber informasi yang mereka percayai.

\section{i. Transmedia Navigation}

Transmedia Navigation berkaitan dengan kemampuan mengikuti alur informasi, memburu dan mengumpulkan informasi. Hal ini berarti tidak terbatas pada tulisan saja, tetapi juga pada media berbentuk gambar dan video. Hasil tabulasi data mahasiswa untuk indikator Transmedia Navigation tampak sebagaimana tabel berikut:

Tabel 9. Distribusi Frekuensi Indikator Transmedia Navigation

\begin{tabular}{|c|c|c|}
\hline Keterangan & $\mathbf{F}$ & $\%$ \\
\hline Selalu & 81 & 30,34 \\
\hline Sering & 163 & 61,05 \\
\hline Kadang-kadang & 22 & 8,24 \\
\hline Tidak Pernah & 1 & 0,37 \\
\hline Jumlah & 267 & 100 \\
\hline
\end{tabular}

Analisis data menunjukkan bahwa responden mampu menceritakan kembali informasi yang didapatnya di internet kepada orang lain, hal itu lebih sering mereka lakukan dari pada hanya sekedar membaaca informasi atau kemampuan up to date terhadap informasi.

\section{j. Networking}

Networking berkaitan dengan kemampuan mencari, mensintesa, dan menyebarkan informasi. Hasil tabulasi data mahasiswa untuk indikator Networking tampak sebagaimana tabel berikut:

Tabel 10. Distribusi Frekuensi Indikator Networking

\begin{tabular}{|c|c|c|}
\hline Keterangan & $\mathbf{F}$ & $\%$ \\
\hline Selalu & 96 & 35,96 \\
\hline Sering & 157 & 58,80 \\
\hline Kadang-kadang & 14 & 5,24 \\
\hline Tidak Pernah & 0 & 0,00 \\
\hline Jumlah & 267 & 100 \\
\hline
\end{tabular}

Hasil analisis data menunjukkan bahwa responden membagikan informasi di internet tetapi kegiatan mencari dan menyelaraskan informasi dengan dunia nyata lebih sering mereka lakukan dari pada membagikan informasi. Hal ini berarti responden lebih mampu untuk mencari informasi dari pada menciptakan informasi.

\section{k. Negotiation}

Negotiation berkaitan dengan kemampuan memahami dan menghargai berbagai perspektif serta berpegang dan mengikuti norma di setiap komunitas. Hasil tabulasi data mahasiswa untuk indikator Negotiation tampak sebagaimana tabel berikut:

Tabel 11. Distribusi Frekuensi Indikator

\begin{tabular}{|c|c|c|}
\hline \multicolumn{1}{|c|}{ Negotiation } \\
\hline Keterangan & F & \% \\
\hline Selalu & 109 & 30,62 \\
\hline Sering & 214 & 60,11 \\
\hline Kadang-kadang & 30 & 8,43 \\
\hline Tidak Pernah & 3 & 0,84 \\
\hline Jumlah & 356 & 100 \\
\hline
\end{tabular}

Sumber : Data Olahan September 2018

Analisis data menunjukkan bahwa dari empat pernyataan mengenai etika bermedia, masih ada tiga item yang tidak pernah dilakukan oleh responden. Tiga item tersebut yaitu tanggapan responden yang menyatakan tidak pernah melakukan pemilihan kepada orangorang tertentu ketika menyebarkan informasi maupun tanggapan responden yang merasa tidak pernah mengkonformasi kembali ketika menyadari bahwa mereka telah menyebarkan informasi yang salah.

\section{l. Visualisation}

Secara sederhana dapat diartikan kemampuan membuat dan mengolah sendiri informasi sebelum dibagikan dan disebarluaskan di internet. Hasil tabulasi data mahasiswa untuk indikator Negotiation tampak sebagaimana tabel berikut:

Tabel 12. Distribusi Frekuensi Indikator Visualisantion

\begin{tabular}{|c|c|c|}
\hline Keterangan & $\mathbf{F}$ & $\%$ \\
\hline Selalu & 43 & 16,10 \\
\hline Sering & 159 & 59,55 \\
\hline Kadang-kadang & 59 & 22,10 \\
\hline Tidak Pernah & 6 & 2,25 \\
\hline Jumlah & 267 & 100,00 \\
\hline
\end{tabular}

Analisis data menggambarkan bahwa masih ada 6 item atau 2,25\% tanggapan yang 
menyatakaan bahwa mereka belum mampu mengolah informasi yang didapatnya dari internet dan membagikan kembali informasi tersebut dengan bahasanya sendiri. Kemudian mereka juga belum mampu menciptakan informasi lewat media gambar dan video.

\subsection{Literasi Media Baru Mahasiswa Fakultas Agama Islam Universitas Islam Riau}

Hasil rekapitulasi data literasi media baru mahasiswa Fakultas Agama Islam Universitas Islam Riau tampak sebagaimana tabel berikut:

Tabel 13. Distribusi Frekuensi Literasi Media Baru Mahasiswa

\begin{tabular}{|c|c|c|}
\hline Keterangan & $\mathbf{F}$ & $\%$ \\
\hline Selalu & 920 & 28,71 \\
\hline Sering & 1996 & 62,30 \\
\hline Kadang-kadang & 272 & 8,49 \\
\hline Tidak Pernah & 16 & 0,50 \\
\hline Jumlah & 3204 & 100,00 \\
\hline
\end{tabular}

Berdasarkan tabel dan diagram tersebut, terlihat bahwa jawaban tertinggi ada pada responden yang menganggapi sering memperhatikan literasi ketika memanfaatkan media baru dengan persentase jawaban $62,30 \%$. Sementara yang tidak pernah melakukan literasi ketika memanfaatkan media baru ada 0,50\%. Adapun yang kadang-kadang melakukan literasi saat memanfaatkan media baru ada pada persentase $8,49 \%$ dan yang selalu memperhatikan literasi sewaktu memanfaatkan media baru hanya $29,71 \%$.

Terlihat bahwa persentase tertinggi ada pada indikator Performance yaitu sebesar $84,41 \%$. Hal ini berati kemampuan responden dalam membaca, mempelajari, dan mengambil dampak positif dari memanfaatkan media baru tergolong sangat baik. Jawaban tertinggi ke-2 ada pada indikator Play dengan persentase $82,96 \%$. Hal ini berarti kemampuan responden dalam mengakses dan mengeksplorasi media baru tergolong sangat baik. Kemudian kemampuan tertinggi ke-3 ada pada indikator Networking dengan persentase sebesar $82,68 \%$. Hal ini berarti kemampuan responden dalam mencari, mensintesa, dan menyebarkan informasi pada media baru tergolong sangat baik. Selanjutnya ada indikator Visualisantion dengan persentase $82,23 \%$. Hal ini dapat diartikan kemampuan responden dalam membuat serta mengolah sendiri informasi sebelum dibagikan dan disebarluaskan di internet ada pada kategori sangat baik. Peringkat selanjutnya adalah indikator Distributed Cognition dengan persentase sebesar $81,60 \%$ dan terletak pada rentang nilai 76 $100 \%$ dalam artian kemampuan responden memahami segala elemen yang sering ditemui di media baru termasuk pada kategori sangat baik. Indikator Transmedia Navigation dengan persentase $80,34 \%$ yang berarti kemampuan responden dalam hal mengikuti alur informasi, memburu dan mengumpulkan informasi yang tidak hanya terbatas pada teks saja tetapi juga informasi yang berbentuk gambar dan video dikategorikan sangat baik. Indikator Negotiation dengan persentase $80,13 \%$, yang diartikan kemampuan responden dalam hal memahami dan menghargai berbagai perspektif serta berpegang serta mengikuti norma di setiap komunitas juga tergolong sangat baik.

Lima indikator selanjutnya juga masih ada pada rentang nilai $76-100 \%$ dan termasuk pada kategori sangat baik, hanya saja persentasenya di bawah 80\%. Adapun urutannya adalah indikator Simulation dengan persentase 79,14\%, berarti kemampuan mempertanyakan kebenaran informasi, membandingkan dengan konteks dunia nyata, membandingkan dengan sumber lain serta memberikan penilain akhir terhadap informasi yang diterima dari media baru oleh responden termasuk sangat baik. Indikator Appropriation dengan persentase $78,93 \%$. Hal ini berarti kemampuan responden dalam hal mengutip informasi dari media baru dengan mencantumkan sumber informasi serta memahami konsekuensi dari membagikan informasi di dunia maya juga berada dalam kategori sangat baik. Indikator Judgment dengan persentase 78,00\%, hal ini dapat diartikan bahwa kemampuan responden mengevaluasi keandalan dan kredibiltas sumber-sumber informasi yang berbeda sudah tergolong sangat baik. Indikator Collective Intelligence dengan persentase sebesar $77,67 \%$, yang dapat diartikan bahwa kemapuan responden yang berkaitan dengan menyatukan dan membandingkan pendapat pengguna dengan pendapat orang lain untuk tujuan bersama juga termasuk dalam kategori sangat baik. Terakhir ada indikator Multitasking dengan persentase 77,53\%. Hal ini menunjukkan bahwa kemampuan responden melakukan pemindaian terhadap informasi yang tidak dibutuhkan serta fokus terhadap informasi yang berguna dan diperlukan saja ada pada kategori sangat baik. Jadi secara keseluruhan, literasi media baru Mahasiswa Fakultas Agama Islam Universitas Islam Riau ada pada persentase $79,81 \%$ dan ada 
pada rentang nilai $76-100 \%$ serta termasuk dalam kategori sangat baik.

Jika digambarkan dalam bentuk garis kontinum, maka akan tampak sebagaimana gambar berikut:

\section{Gambar 18. Hasil Skor Penelitian Pada Garis} Kontinum

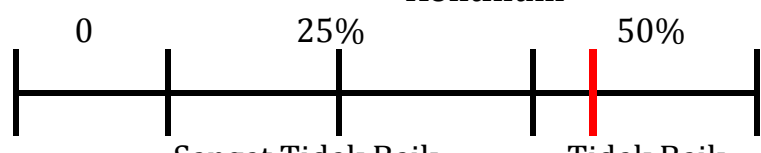
Sangat Tidak Baik Tidak Baik

Sumber: Data Olahan September 2018

\section{Penutup}

\subsection{Kesimpulan}

Dapat disimpulkan bahwa secara keseluruhan, literasi media baru mahasiswa Fakutas Agama Islam Universitas Islam Riau termasuk pada kategori sangat baik dengan persentase $79,81 \%$. Kemampuan tertinggi berada pada indikator Performance yaitu $84,41 \%$ termasuk pada kategori sangat baik. Kemudian di posisi ke dua yaitu indikator Play dengan persentase sebesar 82,96\% termasuk pada kategori sangat baik. Di posisi ke tiga adalah indikator Networking dengan persentase sebesar $82,68 \%$ termasuk pada kategori sangat baik. Posisi ke empat adalah Visualisation dengan persentase sebesar 82,23\% termasuk pada kategori sangat baik. Posisi ke lima dan ke enam ada pada indikator Distributed Cognition dan Transmedia Navigation dengan persentase masing-masing sebesar $81,60 \%$ dan $80,34 \%$ termasuk pada kategori sangat baik. Posisi ke tujuh adalah Negotiation dengan persentase sebesar $80,13 \%$ termasuk dala kategori sangat baik. Sisanya juga termasuk dalam kategori sangat baik namun dengan persentase di bawah $80 \%$, yaitu di posisi delapan dan sembilan yang ditempati oleh Simulation dan Appropriation dengan persentase masing-masing sebesar $79,14 \%$ dan 78,93\%. Indikator Judgment dengan persentase sebesar 78,00\%, Collective Intelligence dengan persentase sebesar $77,67 \%$ dan peringkat terbawah ada pada indikator Multitasking dengan persentase sebesar 77,53\%.

\subsection{Saran}

Berdasarkan kesimpulan di atas, perlu adanya beberapa masukan demi meningkatkan kemampuan literasi media baru mahasiswa Fakultas Agama Islam Universitas Islam Riau untuk kedepannya.Untuk kemampuan Multitasking dan Collective Intelegence perlu mengadakan program kuliah umum atau pelatihan yang mengangkat tema literasi media baru maupun dengan mengikut sertakan pustakawan terutama dalam hal memperkenalkan situs-situs edukasi yang bermanfaat. Untuk kemampuan Judgment dan Simulation bisa ditingkatkan oleh dosen terutama untuk mata kuliah yang berkaitan dengan Pendidikan Agama Islam yaitu menyampaikan materi tentang menganalisa keterpercayaan sumber informasi serta

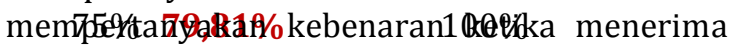
informasi di media baru. Sedangkan untuk kemampuan Appropriation bisa dilakukan oleh doseBaik mata ksqlägat BaikPendidikan Kewarganegaraan atau dosen di bidang hukum agar mahasiswa memahami konsekuensi dari membagikan informasi di dunia maya.

\section{Daftar Pustaka}

Ardianto, Elvinaro, Lukiati Komala, Siti Karlinah. 2009. Komunikasi Massa: Suatu Pengantar. Jakarta: Simbiosa Rekatama Media.

Baran, Stanley J. 2012. Pengantar Komunikasi Massa: Melek Media dan Budaya. Jakarta: Erlangga.

Danim, Sudarman. 2007. Metode Penelitian untuk Ilmu-Ilmu Prilaku. Jakarta: Bumi Aksara.

Islaminingsih, Riski Nur; Erwina, Wina; Rohman, Asep Saeful. 2012. "Literasi Informasi dan Media bagi Siswa dalam Menunjang Pengerjaan Tugas Sekolah." eJurnal Mahasiswa Universitas Padjajaran: Vol.1 No.1.

http://jurnal.unpad.ac.id/ejournal/article /view/1507/pdf. Diakses Rabu, 14 Maret 2018 Pukul 16:21

Lasa Hs. 2009. Kamus Kepustakawanan Indonesia. Yogyakarta: Pustaka Book Publisher.

Lien, Diao Ai. 2014. Literasi Informasi: 7 Langkah Knowlaedge Management. Jakarta: Universitas Atma Jaya.

Mutmainah, Anna. 2017. "Tingkat Literasi Media Mahasiswa Komunikasi Surakarta tentang Pemberitaan Kopi Beracun Sianida di TV One (Studi Kasus Mahasiswa Komunikasi UNS, UMS, dan IAIN Surakarta)." Jurusan Komunikasi dan Penyiaran Islam Fakultas Ushuluddin dan Dakwah Institut Agama Islam Negeri Surakarta. 
Rijjal, Muhamad Nurur. 2015. “Tingkat Kemampuan Literasi Media Baru Mahasiswa Universitas Riau." Jom FISIP Volume 2 No.1 Februari 2015. http://download.portalgaruda.org/article .php?article $=294853 \&$ val $=6444 \&$ title $=\mathrm{Ti}$ ngkat\%20Kemampuan\%20Literasi\%20M edia\%20Baru\%20Mahasiswa\%20Univers itas\%20Riau. Diakses Kamis, 22 November 2018 Pukul 16:15.

Romli, Asep Syamsul M. 2012. Jurnalistik Online: Panduan Praktis Mengelola. Media Online. Bandung: Nuansa Cendikia.

Siregar, Syofian. 2014. Metode Penelitian Kuantitatif: Dilengkapi Perbandingan Perhitungan Manual dan SPSS. Jakarta: Prenada Media.

Siyamitri, Puty. 2015. “Literasi Media Internet pada Kalangan Guru Menengah Kejuruan di Kota Medan." Jurnal Simbolika Vol. No. 2. https://jurnalsimbolika.files.wordpress.c om/2016/04/puty-siyamitri.pdf. Diakses Rabu, 14 Maret 2018 Pukul 16:27.

Yulianti, Retno. 2013. Literasi Informasi Pemustaka di Perpustakaan STMIK AKOM Yogyakarta berdasarkan Model The Seven Pillars. Yogyakarta. UIN Sunan Kalijaga. http://digilib.uinsuka.ac.id/9011/1/BAB\%20I\%2C\%20V \%2C\%20DAFTAR\%20PUSTAKA.pdf. Diakses Senin, 28 Mei 2018 Pukul 08:53.

Yusup, Prawit M. 2016. Ilmu Informasi, Komunikasi dan Kepustakaan. Jakarta: Bumi Aksara. 